\title{
A MEGOSZTÁSON ALAPULÓ GAZDASÁG KÖRNYEZETI ÉS TÁRSADALMI HATÁSAI
}

\section{ENVIRONMENTAL AND SOCIAL IMPACTS OF SHARING ECONOMY}

\author{
Soltész Petra ${ }^{1}$, Zilahy Gyula ${ }^{2}$ \\ ${ }^{1}$ PhD-hallgató, Budapesti Múszaki és Gazdaságtudományi Egyetem \\ Gazdaság- és Társadalomtudományi Kar Környezetgazdaságtan Tanszék \\ solteszp@eik.bme.hu \\ 2 egyetemi tanár, Budapesti Mǘszaki és Gazdaságtudományi Egyetem, \\ Gazdaság- és Társadalomtudományi Kar, Környezetgazdaságtan Tanszék \\ zilahy@eik.bme.hu
}

\section{ÖSSZEFOGLALÁS}

A megosztáson alapuló, az ún. sharing economy keretein belül működő vállalkozások gyors térnyerése egyre inkább szembetűnő, és a tudományos élet figyelmét is felkeltette. Az üzleti tevékenység ezen új formáját számos szempontból lehet és érdemes is vizsgálni: gazdasági, környezeti és társadalmi hatásait, jogi aspektusait, a működéssel kapcsolatos etikai kérdéseket. Ezen szempontok együttes vizsgálatával talán megválaszolható az a kérdés is, hogy vajon a sharing economy vállalkozásai mennyire segítik elő a fenntartható fejlődés megvalósítását. Jelen cikkben a sharing economy által a fenntartható fejlődés szempontjából felvetett kérdéseket mutatjuk be a témával kapcsolatos egyre kiterjedtebb szakirodalom alapján, leginkább a környezeti és társadalmi hatásokat a középpontba helyezve. E vállalatok hatásainak vizsgálata nemcsak egyre nagyobb méretük miatt elengedhetetlen, hanem azért is, mert megjelenésükkel alapvetően változnak meg a vállalati folyamatokon kívül a fogyasztói magatartás legfontosabb megnyilvánulásai is. A piacon megjelent egyre több, a sharing economy területén működő vállalkozás gyakran hivatkozik a társadalomra és a természetes környezetre kifejtett pozitív hatásokra, azonban nehéz átfogó képet alkotni ezekről a konkrét megvalósítási módonként is igen eltérő hatásokról.

\section{ABSTRACT}

The rapid growth of companies operating in the 'sharing economy' has become increasingly prominent and has attracted the attention of the scientific community. This new form of business activity can and should be considered from many different aspects: economic, environmental and social impacts, legal and ethical issues should be taken into account to be able to answer the question whether sharing economy businesses can contribute to the implementation of sustainable development. In this article, we present the issues raised by the sharing econ- 
omy with regard to sustainable development, based on the growing literature and focusing on the environmental and social implications. Investigating the impact of these companies is not only necessary due to their increasing importance, but also because their appearance is already fundamentally changing the most important manifestations of consumer behaviour. The increasing number of companies in the market operating in the sharing economy often refer to the positive effects they have on society and the natural environment, but it is difficult to have a comprehensive picture of these and they can vary greatly from one organization to another.

Kulcsszavak: megosztáson alapuló gazdaság, sharing economy, környezeti hatás, társadalmi hatás, visszapattanó hatás, fenntartható üzleti modell, fenntartható fejlődés

Keywords: collaborative consumption, sharing economy, environmental impact, social impact, rebound effect, sustainable business model, sustainable development

\section{BEVEZETÉS}

Az innovatív üzleti modellek megjelenése egyre több kutatót ösztönöz az új üzleti modellekkel rendelkező vállalatok különféle szempontok szerinti vizsgálatára. Ezen belül is egyre nagyobb figyelem irányul a sharing economy (magyarul közösségi gazdaság vagy megosztáson alapuló gazdaság) működésére, az elterjedését elősegítő és gátló tényezőkre, az elterjedésével kapcsolatos várható hatásokra, illetve a területen alkalmazható szabályozó eszközökre. Jelen cikk fókuszában az innovatív üzleti modellek közül a sharing economy keretében müködő vállalkozásokkal kapcsolatos kutatások eredményeinek bemutatása áll, különös figyelmet szentelve e szervezetek környezeti és társadalmi hatásainak.

A terület gyors fejlödésének egyik eredménye, hogy a sharing economy jelenségének számos, többé-kevésbé eltérő meghatározása terjedt el a szakirodalomban (Schor, 2014). A következő részben e kérdéskört járjuk körül a sharing economy vállalkozásait jellemző működés bemutatásán keresztül, majd részletesen ismertetjük a tudomány által napjainkig azonosított, a fenntartható fejlődésre gyakorolt hatásokat.

\section{A MEGOSZTÁSON ALAPULÓ GAZDASÁG MINT ÜZLETI MODELL JELLEMZŐI}

A szakirodalomban megvizsgált cikkek két nagy csoportra oszthatók: a sharing economyt mint jelenséget leíró cikkekre, illetve a megosztáson alapuló vállalkozások tevékenységéből eredő hatásokat vizsgáló kutatásokra.

A megosztáson alapuló gazdaságot leggyakrabban a gazdaság olyan ágaként tekintik, amely kihasználatlan erőforrásokat von be a gazdasági életbe, legyenek 
azok tárgyak, terek vagy tudás (lásd például Botsman, 2013). Bár a megosztáson alapuló üzleti modellt egyre újabb területeken alkalmazzák, elsősorban azok az eszközök alkalmasak a megosztásra, melyek viszonylag jelentős értéket képviselnek a fogyasztók számára, mégis nagy mennyiségben állnak rendelkezésre. Ezeket ún. mid-grained jószágoknak hívjuk (Lamberton, 2016).

A megosztott erőforrások igénybevétele történhet pénzügyi ellenszolgáltatás fejében vagy anélkül. A napjainkban elterjedő megoldások alapját képező, már hagyományosnak tekinthető első kezdeményezések jellemzően közvetlen ellenszolgáltatás nélkül voltak igénybe vehetők (lásd például couchsurfing). Ahogy azonban a felhasználók egyre inkább megtapasztalták az ilyen jellegủ szolgáltatások előnyeit, az üzleti élet szereplöi is felismerték a bennük rejlő lehetőségeket, és a kezdeti kezdeményezéseket profitorientált vállalkozások váltották fel, ami egyúttal e korai megoldások piacról való kiszorulásával is együtt járt. Ezáltal az egyes megosztáson alapuló kezdeményezések célja is eltolódott a környezeti és társadalmi problémák kezelése felől a profitszerzés irányába, ami kritikákat váltott ki ezen vállalkozásokkal szemben, illetve a különböző célú megoldások elnevezésének a szétválásához vezetett.

A megosztáson alapuló gazdaság egyik legfontosabb jellemzője, hogy müködése online platformok segítségével valósul meg, amelyek lehetővé teszik a kereslet és a kínálat egymásra találását (Wosskow, 2014). Bár az internethasználat általánossá válása (különösen a mobil eszközökön) és online platformok nélkül a legtöbb sharing economy kezdeményezés nem volna képes nagyszámú felhasználó elérésére, ezeket mégis csak mintegy eszközöknek tekinthetjük egyébként off-line tevékenységek végzéséhez (Schor, 2014).

A sharing economy gyors térnyerésének szükséges, de nem elégséges feltétele az internethasználat általánossá válása: feltételezi továbbá a fogyasztók gazdasági racionalitását és árérzékenységét, a fogyasztói szokások megváltozását, valamint a városiasodás és egyéb társadalmi szokások változásait is $(\mathrm{PwC}$, 2015). Ennek köszönhető, hogy a fiatalabb generációk rugalmasabb hozzáállásuk miatt gyakrabban használják az ilyen vállalatok szolgáltatásait (Frost \& Sullivan, 2010).

A sharing economy megközelíthető a használaton kívüli eszközökhöz való idöszakos hozzáférés biztosításával járó gazdasági hatások szempontjából is (lásd például Böcker-Meelen, 2017; Frenken, 2017). A megosztás segítségével jövedelemre lehet szert tenni, illetve felhasználói erőforrásokat takaríthatnak meg, vagy olyan szolgáltatásokhoz juthatnak, melyeket korábban nem, vagy csak nagyobb erőfeszítés árán engedhettek meg maguknak. A megvalósulás során pénzbeli ellenszolgáltatás jár a nyújtott szolgáltatásért (Botsman, 2013; Belk, 2014; BöckerMeelen, 2017).

A terület újszerűségét jól mutatja a szakirodalomban fellelhető megnevezések sokszínüsége is. 
Collaborative consumptionról (együttmüködésen alapuló fogyasztásról) beszélünk, amikor „,a felhasználók koordinálásával valamely erőforrás megszerzésére és újraelosztására kerül sor pénzbeli ellenszolgáltatás vagy egyéb kompenzáció ellenében" (Belk, 2014, 1597.). Egy másik, gyakran alkalmazott kifejezés a peer economy (felhasználók gazdasága), melynek két fontos jellemzöje van: az internetalapú összekapcsolás, illetve a javak, erőforrások kihasználása (Bellotti et al., 2015). A peer economy vagy peer-to-peer economy kifejezetten azokra a megoldásokra vonatkozik, ahol a kereslet és kínálat tárgyát jelentő javak is magánszemélyek kezében vannak (például: Airbnb, Oszkár, gardrobcsere.hu) (lásd Selloni, 2017).

Giana M. Eckhardt és Fleura Bardhi szerint a sharing economy kifejezés alkalmazása nem helyes azokban az esetekben, amikor a megosztás egy piaci szereplő mediáló szerepén alapul (lásd például: Uber, Airbnb). Az ilyen megoldásokat inkább 'access-based economy'-nak kellene hívni, mivel a felhasználók nem közösségi élményt, hanem az olcsó vagy kényelmes megoldásokat keresik, és azok eléréséért fizetnek (Eckhart-Bardhi, 2015).

Jukiet Schor tipizálása szerint három szempont alapján lehet rendszerezni az ismert vállalatokat: a szolgáltatás típusa $(\mathrm{P} 2 \mathrm{P}=$ peer-to-peer, azaz felhasználók között vagy $\mathrm{B} 2 \mathrm{P}=$ business to peer, azaz vállalat és felhasználó között); a platform profitorientált volta (nonprofit vagy forprofit); valamint a felhasználás típusa (javak felhasználásba való visszaáramoltatása, tartós eszközök használatának növelése, szolgáltatások cseréje és jövedelmező eszközök megosztása) szerint (Schor, 2014). Fontos kiemelni, hogy a sharing economyn belül az esetek nagy részében nem fogyasztókról és vállalatokról beszélünk, hanem felhasználókról (például egy Airbnb-felhasználó adhat is bérbe lakást, de foglalhat is utazásai során). Egy másik megközelítés lehatárolta a sharing economyt és a szinonimaként vagy hasonló jelentéssel bíró kifejezéseket, majd meghatározta, hogy a sharing economy tulajdonképpen a peer-to-peer, access (magyarul hozzáférésen alapuló) és circular economy (magyarul körforgásos gazdaság) együttese (Frenken, 2017). Részesei lehetnek mind a P2P, mind a B2P üzleti modellek (Botsman, 2013), de manapság már a B2B-piacok is szerepet kapnak a sharing economyban (Brooks, 2017). Nemcsak nagy-, hanem kisvállalatok is aktívan részt vesznek benne, sőt, kifejezetten mikro-, kis- és középvállalkozások alakulnak az induláskor, melyek gyakran nemzetközi vállalatokká növik ki magukat (például: Airbnb, Uber) (Schor, 2014).

A peer-to-peer gazdaság alapvetően a bizalmon alapszik. Ez mind a vállalat, mind a felhasználók szempontjából fontos: a felhasználók annak a „szolgáltatását" fogják igénybe venni, akiről jó visszajelzéseket találnak, az újonnan belépő felhasználók pedig azért fogják használni az adott platformot, mert látják, hogy a korábbi felhasználók már bizalommal élnek vele szemben (Botsman, 2013). Ezáltal kialakul egy ún. bizalombank, mely egyes vállalatoknak előnyt szerez a piacon, és megnehezíti a versenytársak belépését adott régióban, hiszen az új felhasználók is a jól megszokott platformhoz fognak csatlakozni, mert azt már 
többen használják (Zilahy, 2016). Az ilyen vállalkozások esetében tehát a müködtető vállalatok felé irányuló bizalmon kívül a felhasználók egymásba vetett bizalma is fontos, hiszen csak akkor lehet részese egy fogyasztó a megosztásnak, ha a róla szóló vélemények nagy többsége pozitív, ellenkező esetben előbb-utóbb kirekesztődik a rendszerből.

\section{FENNTARTHATÓ FEJLŐDÉS ÉS A MEGOSZTÁSON ALAPULÓ GAZDASÁG}

A megosztáson alapuló gazdaság gyors terjedésével kapcsolatos egyik legfontosabb kérdés, hogy vajon milyen hatással van a gazdaságra, az érintett társadalmi csoportokra, illetve a természeti és az ember által épített környezetre. Mivel a sharing economy nem egyszerủen egy új termék vagy szolgáltatás, hanem egy olyan új üzleti modell, mely számos ponton jelentősen eltér a vállalatok által követett hagyományos üzleti modellektől (például a tevékenységeket végzők és a fogyasztók összetételében), ezért ezeket a hatásokat igen nehéz felmérni, és nincs konszenzus abban a tekintetben, hogy összességében kedvezően vagy kedvezőtlenül hatnak-e a fenntartható fejlődés megvalósítására.

A gazdasági hatásokat illetően különbséget kell tenni a B2P- és P2P-vállalatok között. A B2P-vállalatoknál a profitszerzés a cél, a vállalatoknak ugyanolyan adózási és járulékfizetési kötelezettségeik vannak, mint a hagyományos - nem megosztáson alapuló - társaiknak. A P2P-vállalatok müködési mechanizmusa azonban eltérő: bár a vállalat általában ezekben az esetekben is profitszerzés céljából jön létre, azonban a tranzakciók a felhasználók között mennek végbe, melynek egyik elsődleges célja a költségmegosztás (például az Oszkárnál a benzinköltség megosztása az utastársakkal).

A sharing economy pozitív gazdasági hatásai közül a legfontosabb az eszközök jobb kihasználásából fakadó költségcsökkentés, mely vállalkozásonként különböző mértékben jelentkezik a felhasználóknál és a platformot szolgáltatóknál.

A sharing economy ezenkívül számos új vállalkozás létrejöttét tette lehetővé, ami élénkíti a gazdaságot, azonban egyúttal a hagyományos üzleti modellt használó vállalatok kiszorulásához is vezethet.

A megosztáson alapuló szolgáltatások nyújtásának jogszabályi, adózási körülményei a gyors elterjedés miatt még a legtöbb országban nem kiforrottak, ezért e vállalatok a ,szürke gazdaságban” müködnek - az általuk nyújtott kedvező árak sokszor részben ennek is köszönhetőek. A felhasználók egyúttal nagyobb kockázatot is vállalnak, és sok esetben a fogyasztóvédelmi szabályok sem alkalmazhatóak rájuk (Hiller, 2017).

A közlekedési vagy utazási szolgáltatásokat nyújtó felhasználók gyakran nem fizetnek tevékenységük után járulékokat és adókat, de egészségügyi és nyugdíjellátásban sem részesülnek (Hiller, 2017). 
A sharing economy keretein belül végzett tevékenységek sokszor egyszerüek, alacsony hozzáadott értéket képviselnek, szemben a technológiai innovációt igénylő megoldásokkal, ami korlátozza a sharing economy hozzájárulását a gazdaság fejlődéséhez. A gazdasági előnyökből ráadásul csak a platformok használói részesülnek, gyakran a jobb anyagi helyzetben élö, városi lakosság képviselői (Goudin, 2016).

További érdekes kérdés, hogy milyen lehetőséget nyújtanak a megosztáson alapuló szolgáltatások a kis- és közepes vállalkozások számára. Bár a legtöbb ilyen platform alacsony befektetéssel, néhány fö részvételével indul, a végül sikeressé válók gyors fejlődési folyamaton keresztül jelentős méretủ hálózatokat építenek ki. Bár méretük a szolgáltatás jellegétől is függ (egy-egy városra, régióra vagy kontinensekre is kiterjedhet), jellemzö, hogy az adott földrajzi terület csak néhány hasonló vállalkozást képes eltartani. Ezért korlátozott a globális szállásmegosztók száma, de valószínüleg egy közepes méretü városban sem lehet életképes két-háromnál több autómegosztó rendszer, ami végül éppen ezek monopólium jellegét eredményezi.

A sharing economy megoldásai mellett szóló legfontosabb érv az eszközök jobb kihasználása által okozott pozitív környezeti hatás, de egyéb pozitív hatások is megjelenhetnek, hiszen a megosztott eszközök általában eltérnek a magántulajdonban lévőktöl. (Például a B2P-flottaüzemeltetők nagyobb arányban használhatnak környezetbarát meghajtást; a magánlakások környezetterhelése alacsonyabb a nagy szállodákénál stb.) Ugyanakkor a P2P-rendszerekben ugyanez nem feltétlenül valósul meg: az Uber-soförök járművei nem feltétlenül környezetbarátabbak a taxivállalatok gépjárműveinél.

Lars Böcker és Toon Meelen (2017) szerint a megosztáson alapuló gazdaság vállalatainak környezeti hatásai ezért meglehetősen kérdésesek. Kutatásuk alapján a felhasználók motivációiban azonban egyértelmủen megmutatkozik a környezet védelmének fontossága: a vizsgálat során autó- és utazásmegosztást, rövid távú lakáskiadást, eszköz- és élelmiszer-megosztást használókat kérdeztek meg motivációikról a fenntarthatóság három pillérére vonatkozóan. Egyértelmüen megállapítható volt a szektoronkénti eltérés és az, hogy a közlekedési szektorban müködő rendszerek felhasználói számára kifejezetten fontosak voltak a környezetvédelmi szempontok.

Felhívva a figyelmet a negatív környezeti hatások lehetőségére, Koen Frenken (2017) rámutat arra, hogy a sharing economy típusú vállalatok esetében is felmerül az intézményi/szakpolitikai beavatkozás szükségessége. A megosztáson alapuló rendszerekkel kapcsolatos kezdeti pozitív hozzáállást (ami gyakran még elegendő gyakorlati tapasztalat hiányában alakult ki) ma már árnyalják a múködés során tapasztalt negatív hatások, ezért akárcsak a hagyományos üzleti modellt alkalmazó vállalatoknál, itt is szükséges lehet a müködés szabályozása. 
2017-ben John Magne Skjelvik és szerzőtársai a norvég tapasztalatokat figyelembe véve elemezték a sharing economy rendszerek hatásait, és megállapították, hogy több ágazatban is megjelentek negatív hatások, amelyeket visszapattanó hatásként is lehet értelmezni. Peter H. G. Berkhout és szerzőtársai (2000) szerint akkor beszélhetünk visszapattanó hatásról, amikor az erőforrás-felhasználás hatékonyságának a növelése által eredményezett költségcsökkenés segítségével megtakarított összeget termékek/szolgáltatások fogyasztására használjuk fel. Ennek egyik fajtája a közvetlen (direkt) visszapattanó hatás, amikor abból az erőforrásból használunk többet, amit éppen megtakarítottunk (például többet autózunk, mert kevesebbet fogyaszt a jármüvünk). A másik lehetőség a közvetett (indirekt) visszapattanó hatás, amikor a megtakarított összeget másik termék/szolgáltatás fogyasztására fordítjuk (például ugyanannyit autózunk, de a megtakarított pénzből termékeket vásárolunk) (Greening et al., 2000). Ezek a fajta visszapattanó hatások a sharing economy esetében is felmerülnek (Skjelvik et al., 2017), de újfajta hatásokkal is számolni kell.

A negatív környezeti hatásokat a közlekedési szektorban vizsgálva megállapíthatjuk, hogy több szinten jelenik meg az üvegházhatású gázok kibocsátásának növekedése. Okai sokszínűek, leginkább a gyakoribb használatból kifolyólag nő meg a kibocsátás (Skjelvik, 2017) a car sharing (GreenGo, DriveNow, Mol LIMO), ride sharing (Oszkár, BlaBlaCar) és ride hailing (Über) területein. A gyakoribb használat mellett számolni kell a hosszabb utak megtételéböl származó környezeti hatásokkal, melyek szintén negatívan befolyásolják a környezetet. Mindemellett a tömegközlekedésről való áttérés (Ottelin et al., 2017) - busz, vonat, metró, villamos helyett - is hozzájárul a visszapattanó hatáshoz.

A gépjármüveket vagy lakásokat megosztó tulajdonosok viselkedését is befolyásolhatja, hogy a tulajdonukban lévő eszközöket mások is használják. Az autótulajdonos például gyakrabban cseréli le az autóját, és nagyobb, jobban felszerelt jármüvet választ annak érdekében, hogy utasai elégedettek legyenek. A lakástulajdonos pedig felújítja, új bútorokkal rendezi be lakását annak érdekében, hogy kedvezőbb értékeléseket kapjon a bérlőitől. Ezek a tényezők mind csökkentik az eszközök közös használatából származó környezeti előnyöket.

A megosztáson alapuló gazdaság egyik legfontosabb társadalmi hatása a rugalmas munkavégzéshez kötődik. Az autómegosztó rendszerek sofőrjei akár befektetés nélkül is belekezdhetnek egy olyan szolgáltatás nyújtásába, melyet saját körülményeikhez igazíthatnak (például csak szabadidejükben végzik). Ez olyan társadalmi csoportokat is bevon a gazdaságba, amelyek eddig valamilyen oknál fogva kívül rekedtek azon.

A szolgáltatásokat igénybe vevők számára pozitív társadalmi hatások egyrészt az alacsonyabb költségekből adódnak (például gyakrabban lehet meglátogatni a családot, barátokat), vagy a csoporthoz való tartozásból kifolyólag jelennek meg. Az Oszkár-felhasználók esetében például sokak számára az új kapcsolatok épí- 
tése, az ismerkedés vagy egyszerúen a másokkal való kontaktus is előnyt jelent (Soltész-Zilahy, 2017). De a ride sharing rendszerek elősegíthetik a munkahelyre való eljutást is (például külföldön munkát végzők számára).

A platformok által létrehozott, korábban már említett „bizalombankok” lehetőséget adnak a felhasználóknak arra, hogy bátran használják ezeket a rendszereket, és nem fognak büncselekménynek áldozatul esni. Ezáltal a sharing economy szolgáltatásai a bizalmat is növelhetik a társadalom tagjai között.

A negatív társadalmi hatások közül az egyik legfontosabb, hogy azon személyek, akik valamely okból kifolyólag nem tudnak részt venni a rendszerek használatában, kirekesztettnek érzik magukat, nem élvezhetik azok előnyeit. Másrészt a hagyományos munkaszerződés nélkül történő munkavégzés számos hátránnyal is jár, mint például a különböző társadalmi juttatásoktól való elesés, ami kockázatossá teszi a megélhetésüket teljes mértékben az ilyen megoldásokra alapozó személyeket.

A szállásmegosztó rendszerek gyakori velejárója, hogy megnöveli az egyébként nem turizmusra berendezkedett ingatlanok forgalmát, zavarja a többi lakót. Ezenkívül általában is hozzájárulnak az utazások számának a növekedéséhez, és ezáltal minden, a turizmushoz köthető negatív környezeti és társadalmi hatáshoz.

\section{KÖVETKEZTETÉSEK ÉS JAVASLATOK}

A sharing economy a gazdasági élet új jelensége, mely egyre inkább teret hódít a mindennapi életünkben. A terület újszerüségét jól mutatja az együtt élő különböző modellek sokszínűsége és az is, hogy a tudományos irodalom még adós a jelenség pontos definiálásával, az egyes megjelenési formák leírásával is.

Növekvő súlya miatt különösen fontos a megosztáson alapuló gazdaság tágabb értelemben vett környezeti és társadalmi hatásainak a vizsgálata, azonban még ezen a területen is csak az első lépéseket tettük meg: kevés a kutatás, és sokszor azok sem tudnak megbízható adatokra támaszkodni.

Az egyes hatások és eredőjük pontos mérése jelentős módszertani problémákat is felvet (Frenken-Schor, 2017). A hatások ellentmondásossága ráadásul a megosztáson alapuló vállalatokat is óvatosságra inti, ezért - és mivel gyakran ők sem rendelkeznek megfelelő információkkal - csak ritkán és akkor is felszínesen kommunikálnak. Ennek ellenére van példa arra, hogy egy-egy vállalat végez felméréseket és elemzéseket a hatások számszerüsítése érdekében, majd kommunikálja az eredményeket (lásd például az Airbnb tanulmányát a vállalat által indukált környezeti és társadalmi hatásokról [Airbnb, 2017]), azonban a vállalati környezeti és társadalmi teljesítményértékelés és kommunikáció hagyományos eszközei csak komoly korlátokkal alkalmazhatóak a megosztáson alapuló vállalkozások esetében. 
Mindebből következik, hogy további kutatásokra van szükség a megosztáson alapuló gazdaság természetének és tágabb értelemben vett hatásainak a megértéséhez, ugyanis csak az így megszerzett információ birtokában lehet megalapozott döntéseket hozni az egyes megoldások támogatását vagy éppen visszaszorítását illetően.

A tanulmány az Emberi Erőforrások Minisztériuma ÚNKP-18-3 kódszámú új nemzeti kiválóság programjának támogatásával készült.

\section{IRODALOM}

Airbnb (2017): Airbnb: Helping Travel Grow Greener. https://www.airbnbcitizen.com/wp-content/uploads/2017/03/Airbnbandsustainabletravel2017.pdf

Belk, R. (2014): You Are What You Can Access: Sharing and Collaborative Consumption Online. Journal of Business Research, 67, 1595-1600. DOI: 10.1016/j.jbusres.2013.10.001, https://www. researchgate.net/publication/262490610_You_are_what_you_can_access_Sharing_and_collaborative_consumption_online

Bellotti, V. - Ambard, A. - Turner, D. et al. (2015): A Muddle of Models of Motivation for Using Peer-to-Peer Economy Systems. In: Proceedings of the $33^{\text {rd }}$ Annual ACM Conference on Human Factors in Computing Systems - CHI '15. DOI: 10.1145/2702123.2702272, https://www. researchgate.net/publication/275653007_A_Muddle_of_Models_of_Motivation_for_Using_ Peer-to-Peer_Economy_Systems

Berkhout, P. H. G. - Muskens, J. C. - Velthuijsen, J. W. et al. (2000): Defining the Rebound Effect. Energy Policy, 28, 425-432, DOI: 10.1016/S0301-4215(00)00022-7, https://www.researchgate. net/publication/222724912_Defining_the_Rebound_Effect

Botsman, R. (2013): The Sharing Economy Lacks A Shared Definition, Fast Company. 11/21/2013, https://www.fastcompany.com/3022028/the-sharing-economy-lacks-a-shared-definition

Böcker, L. - Meelen, T. (2017): Sharing for People, Planet or Profit? Analysing Motivations for Intended Sharing Economy Participation, Environmental Innovation and Societal Transitions, 23, 28-39. DOI: 10.1016/j.eist.2016.09.004

Brooks, C. (2017): The State of the B2B Sharing Economy. https://www.business.com/articles/ b2b-sharing-economy/

Eckhardt, G. M. - Bardhi, F. (2015): The Sharing Economy Isn't About Sharing at All. Harvard Business Review, 28 January 2015. https://hbr.org/2015/01/the-sharing-economy-isnt-aboutsharing-at-all

Frenken, K. (2017): Political Economies and Environmental Futures for the Sharing Economy. Philosophical Transactions of the Royal Society A., 375, 2095. DOI: 10.1098/rsta.2016.0367, https://royalsocietypublishing.org/doi/10.1098/rsta.2016.0367

Frenken, K. - Schor, J. (2017): Putting the Sharing Economy into Perspective. Environmental Innovation and Societal Transitions, 23, 3-10. DOI: 10.1016/j.eist.2017.01.003, https:// www.sciencedirect.com/science/article/pii/S2210422417300114http://dx.doi.org/10.1016/j. eist.2017.01.003

Frost \& Sullivan (ed.) (2010): Sustainable and Innovative Personal Transport Solutions-Strategic Analysis of Carsharing Market in Europe. https://bit.ly/2oGYRE6

Goudin, P. (2016): The Cost of Non-Europe in the Sharing Economy-Economic, Social and Legal Challenges and Opportunities. http://www.europarl.europa.eu/RegData/etudes/STUD/2016/ 558777/EPRS_STU(2016)558777_EN.pdf 
Greening, L. A. - Greene, D. L. - Difiglio, C. (2000): Energy Efficiency and Consumpion - The Rebound Effect - A Survey. Energy Policy, 28, 389-401. DOI: 10.1016/S0301-4215(00)00021-5, https://www.researchgate.net/publication/4946586_Energy_efficiency_and_consumption_-_ the_rebound_effect_-_a_survey

Hiller, W. (ed.) (2017): Mapping the Cost of Non-Europe, 2014-19. 4th ed. http://www.europarl. europa.eu/RegData/etudes/STUD/2017/603239/EPRS_STU(2017)603239_EN.pdf

Lamberton, C. (2016): Collaborative Consumption: A Goal-based Framework. Current Opinion in Psychology, 10, 55-59. DOI: 10.1016/j.copsyc.2015.12.004, https://www.researchgate.net/publication/289367169_Collaborative_consumption_A_goal-based_framework

Ottelin, J. - Heinonen, J. - Junnila, S. (2017): Rebound Effects for Reduced Car Ownership and Driving. In: Kristjánsdóttir, S. (ed.): Nordic Experiences of Sustainable Planning: Policy and Practice. https://bit.ly/363jB9T

PwC (2015): The Sharing Economy. https://www.pwc.fr/fr/assets/files/pdf/2015/05/pwc_etude_ sharing_economy.pdf

Schor, J. (2014): Debating the Sharing Economy Great Transition Initiative Available. http://www. greattransition.org/publication/debating-the-sharing-economy

Selloni, D. (2017): New Forms of Economies: Sharing Economy, Collaborative Consumption, Peer-to-Peer Economy. Research for Development, 15-26. DOI: 10.1007/978-3-319-53243-1_2, https://bit.ly/2BmSCI0

Skjelvik, J. M. - Erlandsen, A. M. - Haavardsholm, O. (2017): Environmental Impacts and Potential of the Sharing Economy. https://www.diva-portal.org/smash/get/diva2:1145502/FULLTEXT01.pdf

Soltész P. - Zilahy Gy. (2017): Innovative Business Models: Sustainable or Not? In: International, Sustainable Development Research Society (ISDRS) (ed.): Advances in Sustainable Development Research: Inclusive Sustainability for Development: How to Engage Academy, Government, Communities and Business. Bogota, Kolumbia, 354-365.

Wosskow, D. (2014): Unlocking the Sharing Economy - An Independent Review. Department for Business, Innovation and Skills, London, Great-Britain, https://bit.ly/2RYucOW

Zilahy Gy. (2016): Sustainable Business Models - What Do Management Theories Say? Vezetéstudomány - Budapest Management Review, 47, 62-72. http://unipub.lib.uni-corvinus.hu/2497/ 